\title{
Improvement of the PVC Window Frame Installation Method Integrated with Gangform and Field Applicability Analysis
}

\author{
Choi, Hyo-Sung ${ }^{1}$ Lee, Jeong-Ho ${ }^{2}$ Yoo, Huyn-Seok ${ }^{3}$ Kim, Young-Suk ${ }^{3 *}$ Han, Seung-Woo ${ }^{3}$ \\ Gyeryong Construction Company, Seo-Gu, Daejeon, 302-717, Korea ${ }^{1}$ \\ Cost Engineering Research Center, Inha University, Nam-Gu, Incheon, 402-751, Korea ${ }^{2}$ \\ Department of Architectural Engineering, Inha University, Nam-Gu, Incheon, 402-751, Korea ${ }^{3}$
}

\begin{abstract}
In apartment housing construction, window frame installation work, which is conducted after the structura framework, is very important, because its completion time directly affects the starting time of successive interio] finishing works, as well as the overall construction period. Construction delays in interior finishing works might occu due to problems inherent to the conventional window frame installation method, such as the poor verticality of window frames, and the water leakage around them. The primary objective of this study is to analyze the problems of : 'Gangform integrated PVC window frame pre-installation method' based on its pilot test results. Next, this study proposes an improved conceptual model that enables the end users to enhance the field applicability of this method ir terms of productivity, time, and cost. The field applicability of the proposed 'Gangform integrated PVC window framt pre-installation method' was also verified through a survey.
\end{abstract}

Keywords : gangform, window frame, pre-installation, field applicability

\section{Introduction}

\subsection{Background and Purpose}

The window is one of the main members that comprises the outer envelope of a building, and provides diverse functions such as energy saving, ventilation and natural lighting[1]. Window work is the finishing work that is commenced first, and has a great influence on the overall construction period of a project, since the start time of subsequent finishing works is determined depending on the execution of window work. In addition, the cost of window work was found to be about $5.93 \%$

Received : April 28, 2011

Revision received : July 18, 2011

Accepted : July 20, 2011

Corresponding author : Kim, Young-Suk

[Tel: 82-32-872-9757, E-mail: youngsuk@inha.ac.kr]

(c)2011 The Korea Institute of Building Construction, All rights reserved. of total construction cost, making it the most costly of all the finishing works[2].

However, window work is vulnerable to several problems, including poor verticality/horizontality of window frame due to damage of the bracket/anchor that fixes window frame to the structures, leakage around the window frame, and poor finishing quality of window frame[3].

In an analysis of the most common defects of apartment houses, the most common building type in Korea, about 13 households out of 100 were found to have windowrelated defects. An investigation of types of consumer damages related to windows found that leakage around the window frame was the most common source of damage, at $67 \%[4]$. Various approaches to this problem have been pursued, including change of bracket structure, development of window pre-installation method and development of assembly window frame, but their field 
applicability was analyzed to be very low. Among these approaches, the Gangform integrated PVC window frame pre-installation method' was developed to shorten the overall construction period through the early start of successive finishing works, and to solve problems related to window frame leakage and poor waterproofing, but it was determined to have shortcomings such as low economic feasibility and delay in construction period.

This study aims to present an improved model based on the required improvements identified through the survey and results of the pilot field application of the "Gangform integrated PVC window frame pre-installation method," the most advanced of the existing window frame construction methods, and to present plans to improve the field applicability of the Gangform integrated PVC window frame pre-installation method. If the proposed improved model of the PVC window frame pre-installation method is applied on a construction site, it is expected to shorten the construction period, improve productivity, obtain economic feasibility and enhance the efficiency of windowrelated works.

\subsection{Scope and Method}

PVC windows hold a market share of approximately $75 \%$ due to their excellent insulation, their water tightness, their high soundproof effects and their flexibility in opening and closing. This study was restricted to the installation of PVC windows, which are most commonly used in apartment houses, and the improvement of the related installation methods.

The approaches pursued in this study were as follows:

1) Analyze Existing Window Construction Process and Problems

The problems related to existing window constructions were analyzed through interviews with managers and workers in the field, as well as through an analysis of the literature and site visits, through which the need to improve the construction method was derived.

2) Analyze Existing Study Trends

This research analyzed technologies derived to solve problems related to window works, such as the Gangform integrated PVC window frame preinstallation method, assemblytype window frames and change of bracket structure. In particular, this research also analyzed the construction process, economic feasibility and construction period of the Gangform integrated PVC window frame pre-installation method developed for shortening the construction period and securing the quality of window frame works.

3) Present Improved Model of Gangform Integrated PVC Window Frame Pre-installation Method

Through survey and analysis, this research derived the main problems of the Gangform integrated PVC window frame pre-installation method and the required improvements, and presented a model for improving the Gangform integrated PVC window frame pre-installation method that can improve work convenience, shorten construction period, improve quality and secure economic feasibility.

4) Analyze Field Applicability and Technical /Economic Feasibility of Improved Model of the Gangform integrated PVC Window Frame Pre-installation Method

This research presented the effects of shortening the construction period through an analysis of the proposed improvements to the Gangform integrated PVC window frame pre-installation method. In addition, this research examined the economic feasibility of the development method through an analysis of the cost of materials used, and examined the field applicability of the proposed improved model through a survey of construction site managers. 


\section{Gurrent Status of Window Frame Construction Methods, and Consideration of Existing Research Trends}

\subsection{Analysis of Existing Window Frame Construction Process and Problems}

1) Analysis of Existing Window Frame Construction Process

Window frame installation methods can be classified into the Later Erection Method and the First Erection Method. Most construction sites use the Later Erection Method, which allows the precise adjustment of the installation position and verticality/horizontality of the window frame within the tolerance of $3 \sim 5 \mathrm{~mm}$ at the time of window frame installation and construction. In the Later Erection Method, the window frame is installed after concrete curing while leaving the opening areas on walls.

The installation process is as shown in Figure 1.

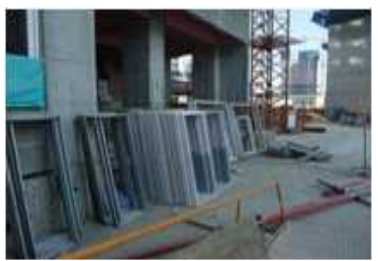

(a) Preparing window frames

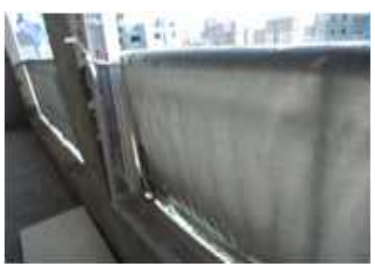

(c) Fixing window frames temporarily

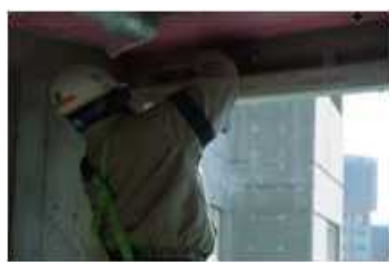

(e) Installing window frames

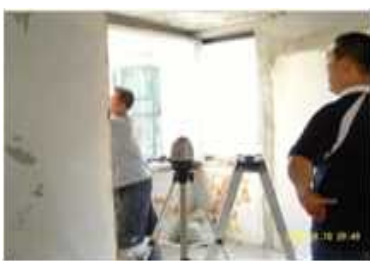

(b) Leveling concrete surface

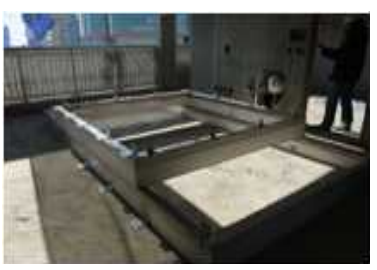

(d) Installing angles

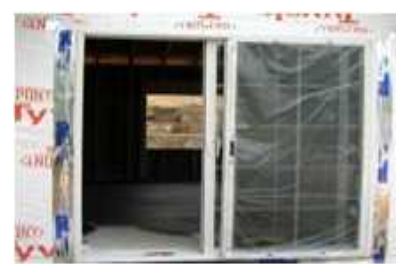

(f) Installing windows

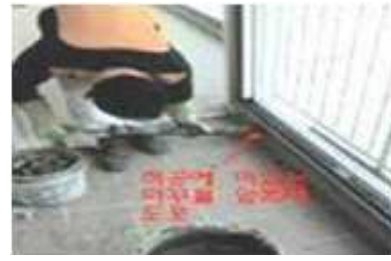

(g) Filling interior plaster

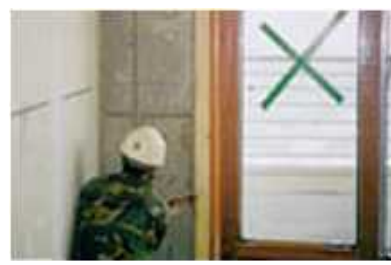

(i) Caulking interior silicon

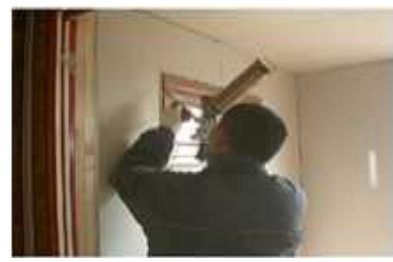

(h) Filling interior urethane

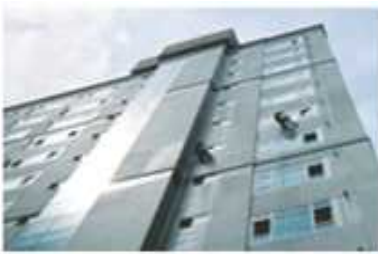

(j) Caulking external silicon
Figure 1. Work process of the window frame installation

That is, windowrelated work is performed in the order of 1) carry in and transport the window materials, 2) level the concrete surface to be connected to the window frame, 3) fix the window frame temporarily, 4) install the bracket for fixing the structure and window frame (in general, Lshaped and T-shaped bracket are installed at intervals of $620 \sim 650 \mathrm{~mm}$ ), 5) fix the window frame using the anchor (install), 6) fill mortar between window frame and structure, 7) urethane filling on the upper and side of window frame, 8) silicon caulking inside the window frame, 9) silicon caulking outside the window frame. While internal silicon caulking is performed for each floor, external caulking is performed on all building windows at once after the completion of the window frame on all floors due to the nature of the work[5]. In most sites, it was found that window frame installation was performed by separating 1 building into 2 sections for convenience of works and the early execution of finishing works. Window frames from the $1^{\text {st }}$ floor to the middle floor were pre-installed, and those from the middle floor to the top floor were postinstalled.

2) Analysis of Problems in Existing Window Frame 
Installation and Construction

With regard to existing window frame installation, the window frame support type using the bracket is preferred, and L-shaped bracket and T-shaped bracket are used (Figure 2).

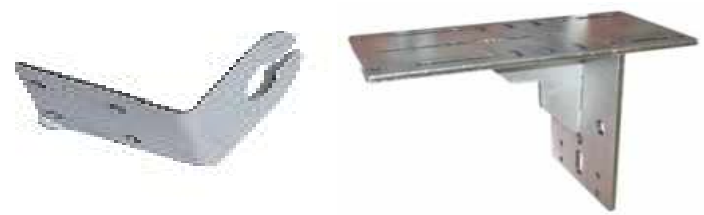

Figure 2. $\mathrm{L}$ and $\mathrm{T}$ type brackets for fixing window frame to concrete structures

When the window frame is fixed using the $\mathrm{L}^{-}$ shaped and T-shaped bracket, the bracket cannot endure the weight of the window frame, resulting in faulty location and sagging of window frame installation due to the transformation of window frame. While the construction method of fixing the bracket to the structure using the anchor has been used, many cases have been reported in which the anchor did not become completely embedded in the structure due to interference with the arranged rebar in the structure. In addition, cases of bending or damaged brackets were also found due to problems of the bracket itself that made it vulnerable to impact (Figure 3).
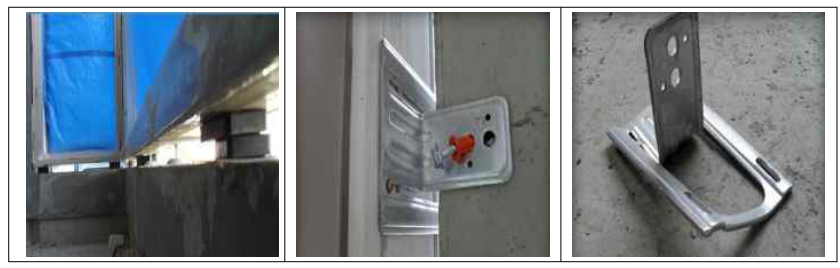

Figure 3. Window frame deflection and bracket distortion problems

While a wooden support is installed on the window frame to improve the problem of the bracket support type, it was found to cause deformation of the window frame, since members such as broken brick or rubber left at the site are used to support the window frame, rather than the installation of a standardized wooden support. While filling work using mortar or urethane as well as caulking work using silicon are conducted to prevent the leakage around the window frame, they were found to have many defects related to water leakage and waterproofness due to damage and deformation of the window frame. In addition, if workers install the lower bracket in a narrow space, workability is reduced. In addition, as all works are executed on-site, from the installation of the window frame and bracket to assembly and installation, the method is found to have low work productivity.

\subsection{Current Status of Main Research on the Construction of Window Frames}

1) Analysis on Current Status of Research and Development

An analysis of previous research related to window construction showed that research and development have been focused on improving the components of the existing window frame installation system, developing auxiliary equipment, and improving the bracket structure for the fixing of window frames and the vertical/horizontal control device of the window frame. The analysis found, however, that the research showed limitations in terms of solving problems of window works such as poor waterproofness and water leakage around the window frame (Table 1). Company L (2010) developed the Gangform integrated PVC window frame pre-installation method with the goal of shortening the construction period through the early start of successive finishing works, achieving a simplification of the process, promoting the convenience of construction and preventing leakage. 


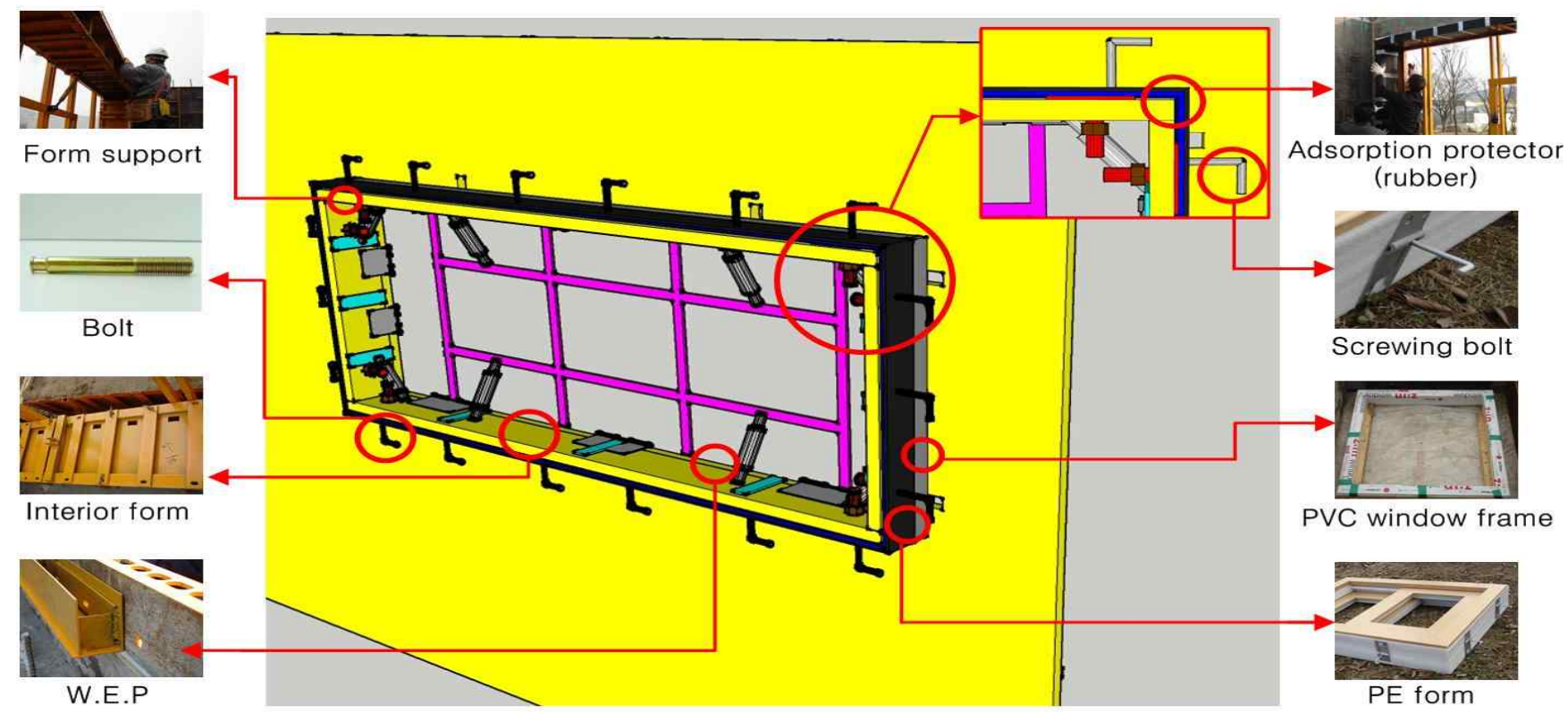

Figure 4. Major components of the PVC window frame installation method integrated with Gangform

However, if this method is applied, it is found to have problems such as low economic feasibility and extension of construction period. Accordingly, this study aims to analyze the problems of the Gangform integrated PVC window frame preinstallation method, which is evaluated to be the most technically advanced of the current window frame construction methods, and to develop a model for its improvement.

2) Composition and Installation Principle of Gangform Integrated PVC Window Frame Pre-Installation Method

Table 1. Major research related to window frames

\begin{tabular}{|c|c|c|}
\hline $\begin{array}{l}\text { Author/ } \\
\text { Inventor }\end{array}$ & $\begin{array}{l}\text { Title of paper/ } \\
\text { Patent } \\
\end{array}$ & Main Content \\
\hline Kim KD & $\begin{array}{l}\text { A Study on the Development of the } \\
\text { Systems for Apartment Doors and } \\
\text { Windows }\end{array}$ & $\begin{array}{l}\text { The new window component system is composed of temporary and prefabricated door frames. The } \\
\text { frames, which are manufactured in simplified standard sizes, are made with aluminum or PVC } \\
\text { material. }\end{array}$ \\
\hline $\begin{array}{l}\text { P company } \\
(2005)\end{array}$ & $\begin{array}{l}\text { A horizontal } \\
\text { and vertical } \\
\text { control device for a } \\
\text { door frame[6] }\end{array}$ & $\begin{array}{c}\text { A Horizontal and vertical control device is a mechanism that controls the fitting of the door frames } \\
\text { by correctly erecting and lining up the support components. }\end{array}$ \\
\hline $\begin{array}{l}\text { P company } \\
(2001)\end{array}$ & $\begin{array}{l}\text { Installation method for } \\
\text { window } \\
\text { frame and } \\
\text { temporary } \\
\text { frame } \\
\text { structure[7] }\end{array}$ & $\begin{array}{l}\text { A structure assembly procedure during which a temporary frame is installed prior to the installation } \\
\text { of window frames to facilitate subsequent finishing and touch up work, and then window frames } \\
\text { are installed after conducting finishing and touch up work }\end{array}$ \\
\hline $\begin{array}{l}\text { L company } \\
(2010)\end{array}$ & $\begin{array}{l}\text { The PVC } \\
\text { Window } \\
\text { Frame } \\
\text { Installation } \\
\text { Integrated with } \\
\text { Gangform[8] }\end{array}$ & $\begin{array}{l}\text { This system is able to achieve the maximum effectiveness in terms of leakage prevention and } \\
\text { waterproofness, because the installation of Gangform and the installation of window frames is } \\
\text { completed before placing concrete, which means that concrete curing and installation of window } \\
\text { frames are completed at the same time }\end{array}$ \\
\hline
\end{tabular}


The Gangform integrated PVC window frame preinstallation method is a method of placing concrete and installing a window frame at the same time, unlike the previous methods, in which the window frame was installed after placing the concrete. This method requires members such as rubber protectors, PE form, window frame mount and WEP (Figure 4). This method is designed to solve waterproofness-related problems and leakage around the window frame, since it enables the adhesion of the structure and window frame through the simultaneous construction of the concrete and the window frame. In addition, since the structure directly supports a window frame that is not the bracket support type, it can solve problems of window frame deformation. The Gangform integrated PVC window frame pre-installation method requires the installation of rubber protectors on 4 sides of the window frame to prevent damage to the window frame due to the movement of workers and the impact of falling of slab and wall form. PE form is installed around the window frame to prevent external water from penetrating inside, through close adhesion between window frame and window.

Figure 5 shows the work process of the Gangform integrated PVC window frame pre-installation method. Similarly to the existing window frame construction method, the work starts with the installation of Gangform ((b) in Figure 5) after carrying in the materials ((a) in Figure 5). Then, WEP is installed to maintain a certain distance between window frame and Gangform on the window frame installation area of Gangform ((c) in Figure 5). The upper window frame support is installed ((d) in Figure 5) and the protector is installed on the upper part of the window frame ((e) in Figure 5). The window frame is mounted on the upper mount, and its verticality/horizontality ((f) in
Figure 5) is checked and adjusted. When the vertical/horizontal status of window frame is confirmed, install protector and mount on the window frame in the remaining area ((g) in Figure 5) and install the internal slab form ((h) in Figure 5).

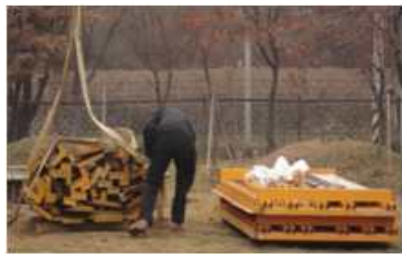

(a) Preparing materials

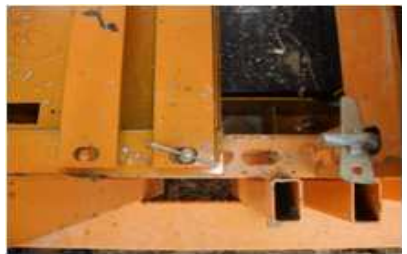

(c) Installing WEP on Gangform

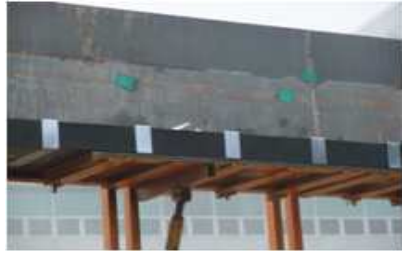

(e) Installing adsorption protector for upper window frame

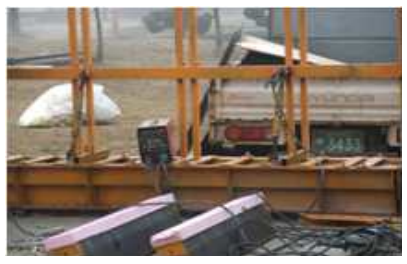

(g) Installing interior adsorption protector

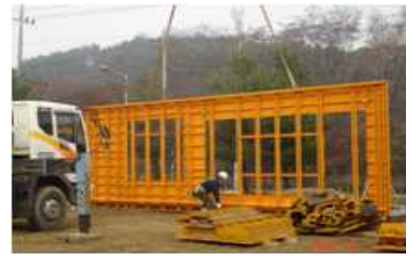

(b) Installing Gangform

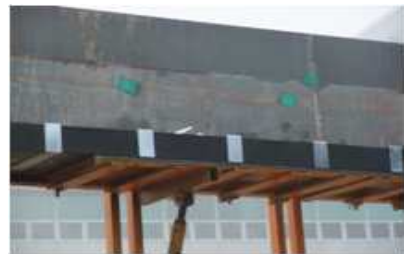

(d) Installing upper window frame support

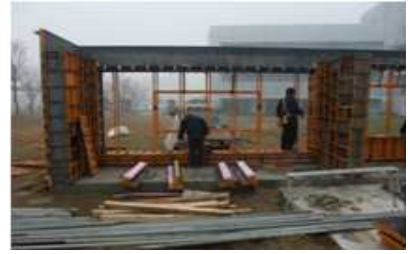

(f) Checking the vertical/horizontal leveling of window frame

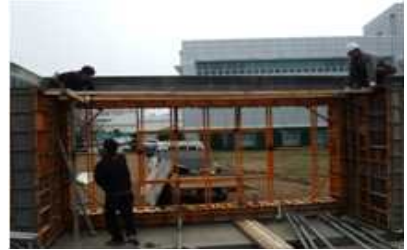

(h) Installing interior slab form
Figure 5. The process of the PVC window frame installation method integrated with Gangform

3) Problems of the Gangform Integrated PVC Window Frame Pre-installation Method and Analysis of Improvements

Technical feasibility, economic feasibility and field feasibility of this method were analyzed through a survey of site managers, site visits and a pilot experiment of the Gangform integrated PVC window frame pre-installation method. The survey was 
conducted on a total of 55 construction site managers and hands-on workers. In the survey, about $51 \%$ of respondents stated that the technical feasibility of the Gangform integrated PVC window frame pre-installation method is low, while $47 \%$ of respondents stated that the economic feasibility of the Gangform integrated PVC window frame preinstallation method is low. This shows that the survey respondents were concerned about economic loss due to the extension of the structure work construction period in the critical path and extremely high unit cost of additional materials such as rubber protectors and PE form.

In terms of the field applicability of the Gangform integrated PVC window frame preinstallation method based on technical and economic feasibility, $65 \%$ of respondents answered that field applicability was low, which might lead to the possibility of increased construction cost, difficulty of work management and extension of construction period compared to the existing work process (Figure 6, 7, 8).
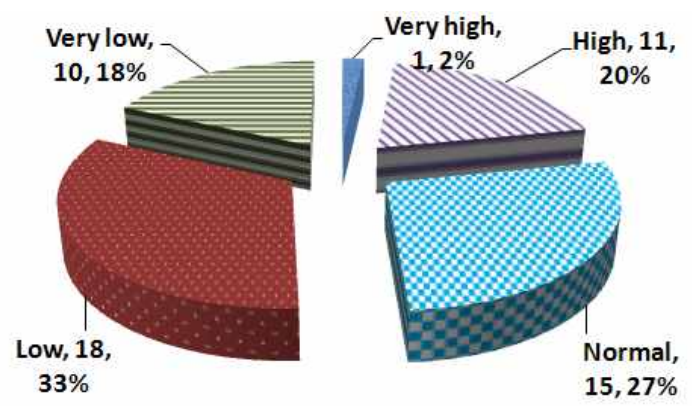

Figure 6.The assessment of technical feasibility

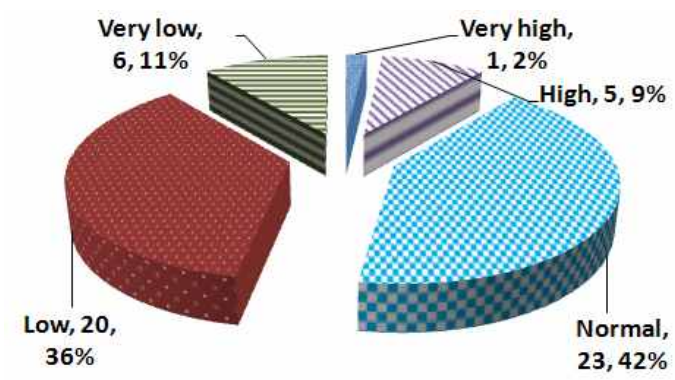

Figure 7. The assessment of economic feasibility

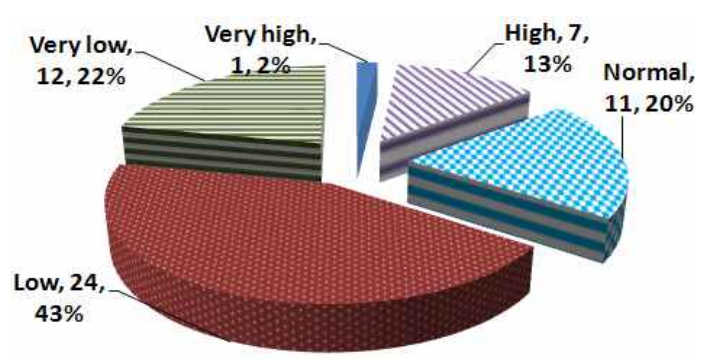

Figure 8. The assessment of field applicability

For this study, a total of 50 construction site managers and specialized contractors were surveyed regarding the problems that should be corrected to improve the site applicability of the Gangform integrated PVC window frame pre-installation method. Table 2 below shows the contents of the survey that was prepared based on the opinions of site managers and the results of pilot field analysis.

Table 2. Enhancements for field application

A. There should be no extension of structure work duration due to
interference between works during structure work
B. Window frames should not be damaged when treating interior wastes
C. Window frames should not be damaged by form dismantling and
other works
D. The wallpaper and finishing materials should not be damaged by
hitting the window frame when window is opened and closed.
E. There should be no probability of re work due to vertical/ horizontal
failure of window frame after concrete curing
F. There should be no difficulty in window frame replacement work
caused by inserted anchor bolt for fixing window frame, including
demolishment work.
G. It should be more economical than the conventional method.
H. Waterproof performance should be equal to or superior to
conventional methods
I. Flexibility of window frame work should be secured, even when the
decision on balcony expansion is delayed.

This study prepared a matrix based on the importance of survey questions and required improvement scores on two axes in order to derive the main required improvements to the Gangform integrated PVC window frame pre-installation method based on the results of the survey (Figure 9). 


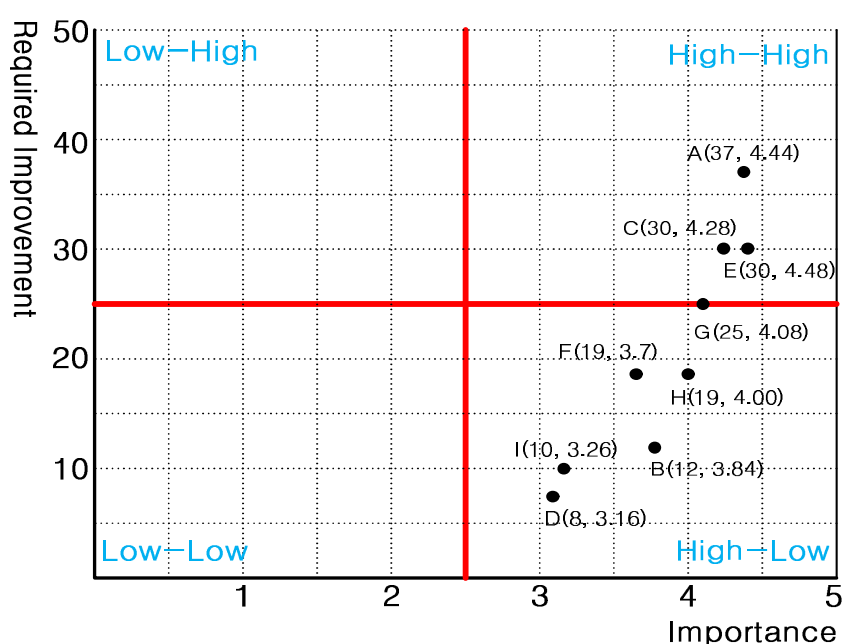

Figure 9. X Y Matrix results on the survey

By evaluating the matrix of importance and required improvements, problems corresponding to A (extension of structure work construction period due to interference between works during structure work), C (damage to window frame pre-installed due to the dismantling of forms and other work), E (generation and difficulty of rework due to poor verticality/horizontality of window frame after concrete curing), G (low economic feasibility compared to the existing method) were found to have high importance in terms of field applicability, and should be addressed. Accordingly, this study addressed the problems of the Gangform integrated PVC window frame pre-installation method that were derived based on site visits and the results of the survey, and proposed an improved model with improved field applicability.

\section{Presentation of Improved Model of Gangform Integrated PVC Window Frame Pre-installation Methods}

Through the survey and pilot field visits to test the Gangform integrated PVC window frame preinstallation method, the Gangform integrated PVC window frame pre-installation method was determined to have a number of main problems, including 1) low economic performance due to the high unit cost of protectors required to prevent damage to the window frame due to the preinstallation of window frame, 2) extension of the construction period due to the mixing of the process of structure work and window frame construction, 3) difficulties in the vertical/horizontal adjustment of window frame. Accordingly, this study plans to present plans to install the protectors on the areas where protection is required only, by identifying the areas and causes of damages on the window frame through an analysis of pilot field experiment results rather than installing protectors on all 4 sides of window frames, in order to solve problems related to low economic performance due to the high unit cost of protectors to prevent damage to the window frame due to the pre-installation of the window frame. In addition, this study will present a Gangform integrated and pre-installed model that can minimize the time required to install the window frame in order to solve the problems related to the extension of construction period due to the mixing of structure work construction and window frame construction process, while devising the fine vertical/horizontal control device that can adjust the verticality/horizontality of the window frame at the same time.

\subsection{Suggestions for Improved Model of Gangform Integrated PVC Window Frame Pre-Installation Method}

\subsubsection{Improvements of Economy from a Management Perspective}

Among the problems of the Gangform integrated PVC window frame pre-installation method, field applicability was found to decline due to low 
economy and inefficiency in the field installation of protectors. Protectors are installed to protect the window frame when treating the wastes, dismantling the form and placing the concrete, and are installed on all 4 sides of the window frames in the Gangform integrated PVC window frame preinstallation method. By analyzing the cause of damage to window frames through field observations of the Gangform integrated PVC window frame pre-installation method, however, most damages to the bottom area of the window frame were found to be attributable to careless movement by workers at the time of waste treatment or form dismantling. Accordingly, the installation of protectors on all 4 sides of the window frame has low effects compared to the input costs. An examination of 34 Pyeong apartment houses found that the window frames installed outside mostly consisted of 5 windows, such as big window and middle-sized window on the balcony area, and 3 small windows. It was necessary to take care to protect the lower part of the frame of the big window and middle-sized window to be used at waste treatment and form dismantling. That is, it is considered to raise the economy by installing high-cost protectors on the points of the window frame that need to be provided with continuous protection.

In addition, our pilot field analysis showed that it took about 70 minutes (for big window and middlesized window) to install protectors, and the mixing with structure work was found to contribute to the extension of the construction period. To solve this, a pre-installation and dedicated use plan of protectors should be presented. In addition, the design of an improved model of window frame preinstallation Gangform should be performed to shorten the time required to install WEP and the window frame mount installation time.

\subsubsection{Suggestion of Integrated Gangform}

This study designed a Gangform system integrating Gangform, mount and protector in order to minimize the interference (mixing) with structure work construction and window frame installation (Figure 10).

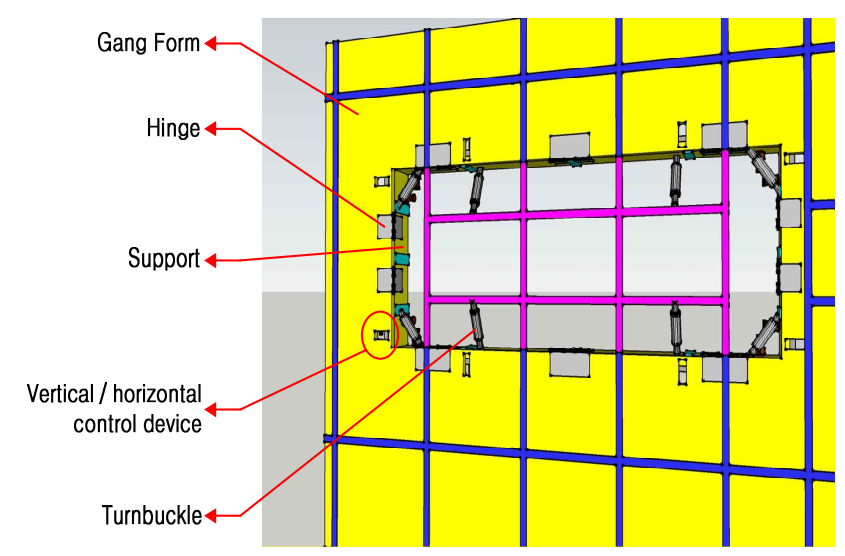

Figure 10. Major components of the new method

The design of an integrated Gangform proposed in this study connected the Gangform to the mount hinge rather than installing the mount at the Gangform. Protector and WEP were also designed to be integrated as one unit. Accordingly, a 7-day cycle structure work construction system was designed by simplifying the installation of mount, WEP and protectors that are required for window frame installation, thus minimizing the mixing with the structure work process. In addition, an integrated Gangform was proposed to prevent damage to the Gangform due to collision with structures and neighboring structures by unfolding the mount in order to prevent damage to the mount at the hoist of Gangform after completion of concrete placement, and to mount the window frame immediately by folding the mount when installing the window frame (Figure 11). 


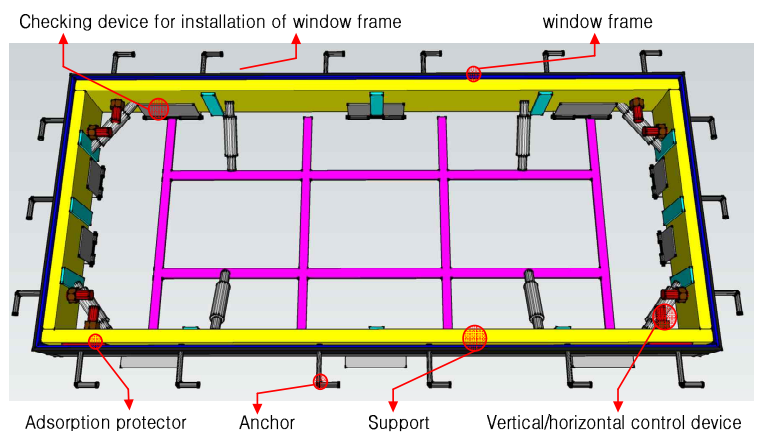

(a) As installing window frame

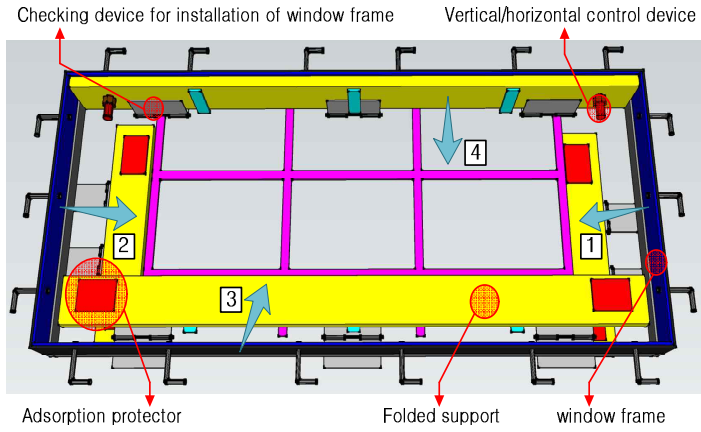

(b) As climbing Gangform

Figure 11. The detailed operation method

\subsubsection{Design of Minute Vertical/Horizontal Control Device}

Gangform integrated PVC window frame preinstallation method could solve the problem of window frame fixation owing to close adhesion of structure and window frame, but it was found to be difficult to check or adjust the verticality/horizontality of window frames that were deformed due to the lateral pressure of concrete after pre-installation. Since the tolerance of structure work construction is $15 \mathrm{~mm}$, which is significantly higher than $3 \mathrm{~mm}$, the tolerance for window work, verticality/horizontality of the window frame should be adjusted precisely in the window frame installation work. That is, the verticality/horizontality of the window frame should be adjusted after the installation of the form, before and after placing concrete, and before the start of curing. Accordingly, this study proposed a plan to easily check the window frame installation status outside the Gangform in order to secure the quality and workability of window frame installation work, and applied it to the improved model of the Gangform integrated PVC window frame preinstallation method (Figure 12).

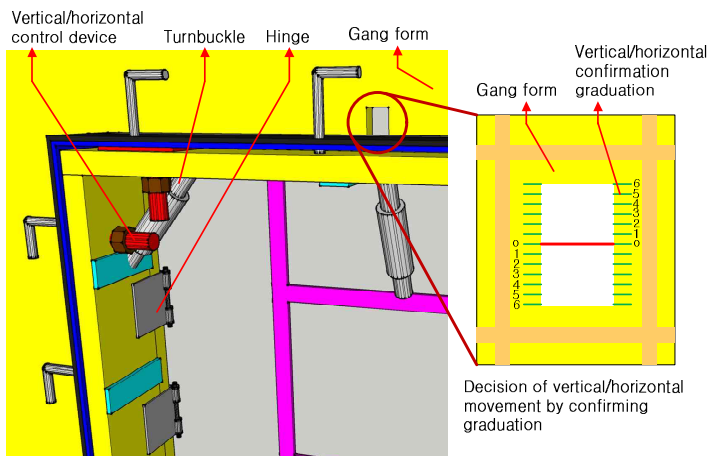

Figure 12. Checking devices for window frame installation

As shown in Figure 12, a hole was punched in the Gangform and WEP was installed inside Gangform to check the installation status of the window frame, so that the verticality/horizontality of the window frame could be checked through vertical/horizontal gradation confirmation indicated on the Gangform. In addition, changes to the installation position of the window frame caused by the lateral pressure of concrete could be checked through vertical $\cdot$ horizontal confirmation graduation. The minute vertical/horizontal control device consists of a control board for adjusting the position of the window frame and a nut for the up and down movement of the control board. It was devised to finely adjust the position of the window frame vertically and horizontally, as the control board of the vertical/horizontal control device moved up and down whenever the nut was loosened or fastened (Figure 13). 


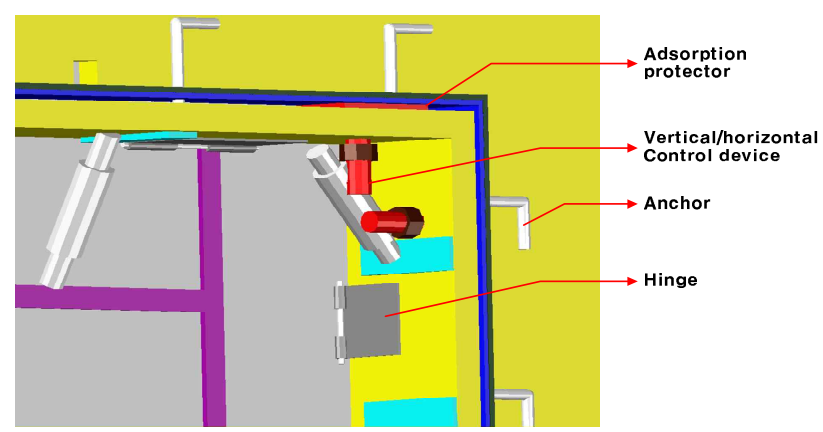

Figure 13. Window frame vertical/horizontal control devices

Precision of window frame installation and construction could be improved by adjusting the bending of the mount through fine vertical/horizontal control.

Precision of window frame installation and construction could be improved by adjusting the bending of mount with the fine vertical/horizontal control device, even if the mount is bent due to the weight of the concrete after concrete placement (Figure 14).

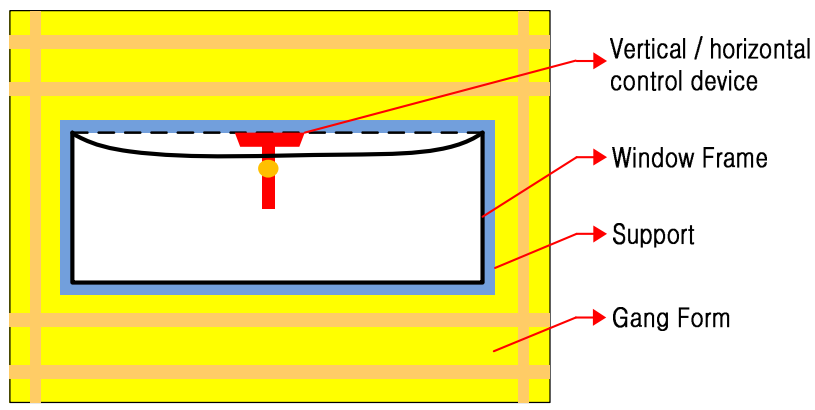

Figure 14. Control devices for preventing deflection of window frame

\section{Analysis of the Validity of the Improved Model of the Gangform Integrated PVC Window Frame Method}

\subsection{Analysis of Construction Period through an Analysis of Productivity for Each Method}

\subsubsection{Analysis of Productivity and Construction Period of Existing Method}

This study analyzed the construction period for each method in order to assess the effects of improved models of the presented Gangform integrated PVC window frame pre-installation method. Construction period was analyzed for 20 floors of 34 Pyeong apartment houses (80 households) (Figure 15).

Since the start time of subsequent finishing works is determined depending on the window frame installation period, precedent and subsequent processes related to window frame installation were considered. In typical window frame installation work, external window frame and internal window frame are installed at the same time after masonry works are completed following concrete curing. After window frame installation, subsequent finishing works are conducted, such as wallpaper work, floor plaster and tile work, and plaster work, in that order.

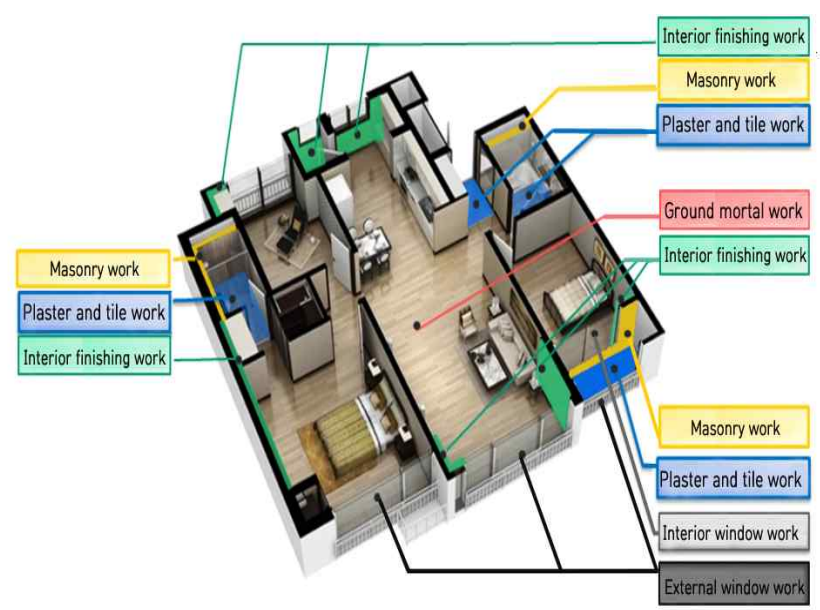

Figure 15. The implement parts of window frame works

This study analyzed the productivity of the existing window frame installation method per work section through interviews with workers and a field survey at 5 apartment sites. The arithmetic mean of data calculated at each site was adopted for productivity data, and workers arranged for the work at 1 building on average were calculated for 
work personnel. Since work was conducted at 1 building for external caulking work, productivity was derived based on 80 households (Table 3).

Table 3. The productivity of conventional window frame installation works

\begin{tabular}{|c|c|c|c|}
\hline Work name & labor & $\begin{array}{c}\text { Productivity } \\
\text { (household/day) }\end{array}$ & $\begin{array}{l}\text { Work duration } \\
\text { (criteria: 10floor } \\
\text { 40household ) }\end{array}$ \\
\hline Masonry work & 2 & 6 & 7days \\
\hline $\begin{array}{l}\text { Window frame lifting } \\
\text { (7ea/household) }\end{array}$ & $7 \sim 9$ & 40 & 1 day \\
\hline $\begin{array}{l}\text { Window frame } \\
\text { installation } \\
\text { (7ea/household) }\end{array}$ & 4 & 12 & 4days \\
\hline $\begin{array}{l}\text { Filling plaster } \\
\text { (7ea/household) }\end{array}$ & 2 & 29 & 2days \\
\hline $\begin{array}{l}\text { Filling urethane } \\
\text { (7ea/household) }\end{array}$ & 1 & 40 & 1 day \\
\hline $\begin{array}{l}\text { Interior silicon caulking } \\
\text { (7ea/household) }\end{array}$ & 3 & 13 & 4days \\
\hline Plaster board work & 3 & 16 & 3days \\
\hline Plaster and tile work & 3 & 15 & 3days \\
\hline Ground mortal work & 4 & 24 & 2days \\
\hline $\begin{array}{l}\text { External silicon caulking } \\
\text { (7ea/household) }\end{array}$ & 6 & 26 & $\begin{array}{c}\text { 4days } \\
\text { (criteria:80household ) }\end{array}$ \\
\hline
\end{tabular}

This study derived the construction period related to window frame and structure work based on 80 households in a single apartment house building based on the derived productivity data. The 7-day cycle process of existing structure work construction was reflected, and the construction period was predicted in consideration of the curing period of each material as well as the concrete age of 28 days.

Existing structure work construction was conducted in the order of Gangform installation for each floor, installation of wall rebar and electricity/facility piping, installation of wall and slab rack, installation of slab rebar, electricity/facility piping, concrete placing and curing in a 7-day cycle in total (Figure 16).

\begin{tabular}{|c|c|c|c|c|c|c|}
\hline $1^{\text {st d day }}$ & $2^{\text {nd }}$ day & $3^{\text {rd d day }}$ & $4^{\text {th }}$ day & $5^{\text {th }}$ day & $6^{\text {th }}$ day & $7^{\text {th }}$ day \\
\hline $\begin{array}{c}\text { Installation } \\
\text { of gang } \\
\text { form }\end{array}$ & $\begin{array}{l}\text { Installation } \\
\text { of wall } \\
\text { rebar }\end{array}$ & $\begin{array}{l}\text { Installation } \\
\text { of wall } \\
\text { form }\end{array}$ & $\begin{array}{c}\text { Installation } \\
\text { of slab } \\
\text { form }\end{array}$ & $\begin{array}{l}\text { Installation } \\
\text { of slab } \\
\text { rebar }\end{array}$ & $\begin{array}{l}\text { Concrete } \\
\text { pouring }\end{array}$ & $\begin{array}{l}\text { Curing \& } \\
\text { lining }\end{array}$ \\
\hline & $\begin{array}{l}\text { Electrical/ } \\
\text { lumbing }\end{array}$ & & & $\begin{array}{l}\text { Electrical } \\
\text { plumbing }\end{array}$ & & \\
\hline
\end{tabular}

Figure 16. Structure work cycles in the conventional method

There are various construction standards related to window frame and interior works of apartment houses, but for this study interior works and the window frame were planned for 4 households of 34pyeong complex in a 20-story apartment building (on the basis of 10 stories as one cycle). Process plan was prepared based on precedent and subsequent works that are directly related to window frame construction (structure work and masonry, wallpaper and plaster work) when calculating the construction period of existing window frame installation work. Weather and other environmental conditions were not considered. Calculating the total construction period of works related to structure work and window frame based on 80 households, it took about 196 days (Figure 17).

\subsubsection{Analysis of Productivity and Construction Period of Gangform integrated PVC window frame pre-installation method}

This study predicted the construction period of the Gangform integrated PVC window frame preinstallation method in consideration of the extension of structure work as well as the survey through pilot field visits to actually measure the productivity of the place to which the Gangform integrated PVC window frame pre-installation method is applied.

Derived productivity data was set as the arithmetic mean of the results of measuring the installation time through a total of 4 rounds of field visits. Table 4 shows the result of measuring 

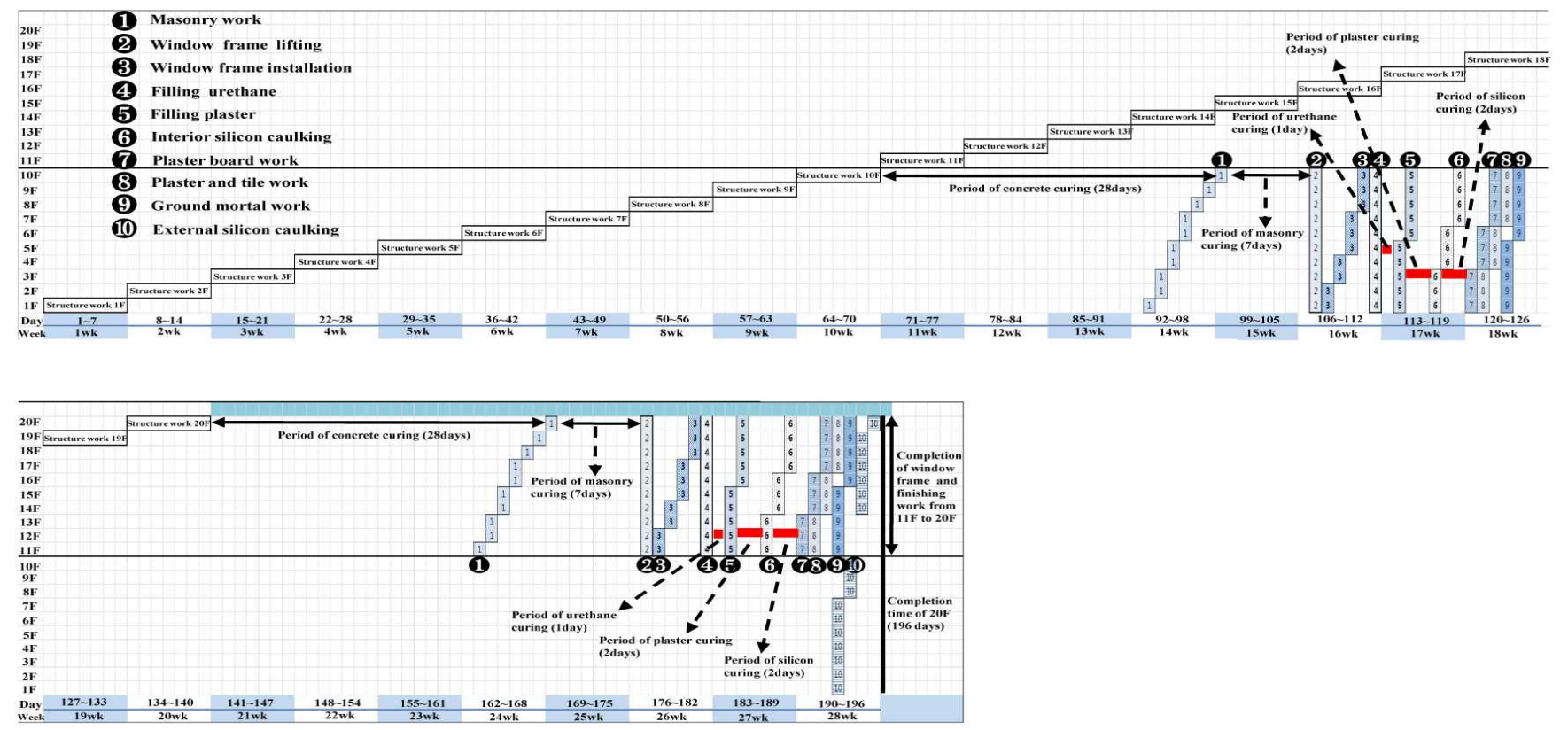

Figure 17. The overall work durations as using conventional method for structure and window frame works

the work time (based on 1 big window, 1 small window) of Gangform integrated PVC window frame pre-installation method.

Table 4. Work duration of each task

\begin{tabular}{cc}
\hline \multicolumn{1}{c}{ Installation work } & Installation time \\
\hline WEP Gangform installation & 60 minutes \\
Installation of upper window frame support & 30 minutes \\
$\begin{array}{c}\text { Installation of adsorption protector to upper } \\
\text { window frame }\end{array}$ & 20minutes \\
Installation of window frame & 2minutes \\
$\begin{array}{c}\text { Installation of adsorption protector to other } \\
\text { sides(left, right, lower) }\end{array}$ & 50minutes \\
$\begin{array}{c}\text { Installation of window frame support to } \\
\text { other sides(left, right, lower) }\end{array}$ & 60minutes \\
\hline
\end{tabular}

Since structure work construction and window frame installation are conducted at the same time in the Gangform integrated PVC window frame preinstallation method, an extra window frame installation period of 1 day is required in addition to the existing 7-day structure work cycle (Figure 18).

Based on the results of an analysis on the productivity of the Gangform integrated PVC window frame pre-installation method and frame work cycle, the number of construction days was drawn on 80 34-Pyeong houses using the same method as the existing window frame installation and construction method.

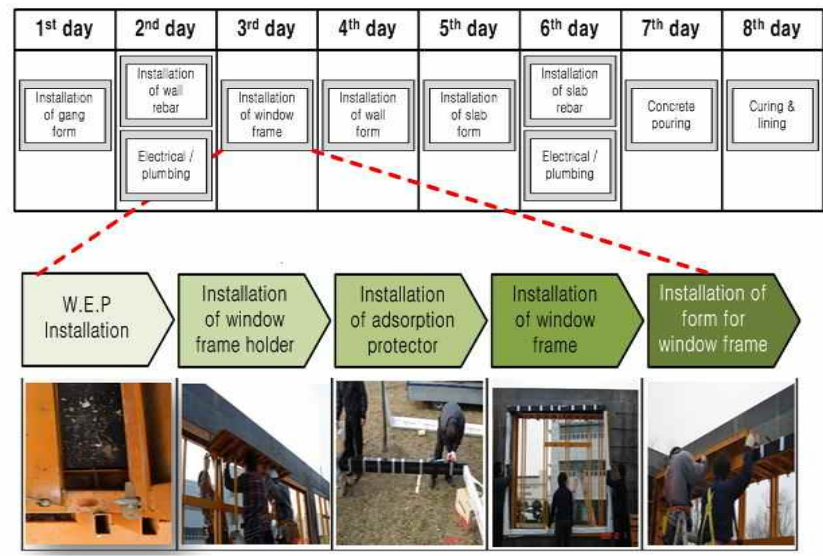

Figure 18. Structure work cycles of the PVC window frame integrated with Gangform

The number of days required for the construction of lamination board related to the installation and construction of window frame, floor plastering, tile, 


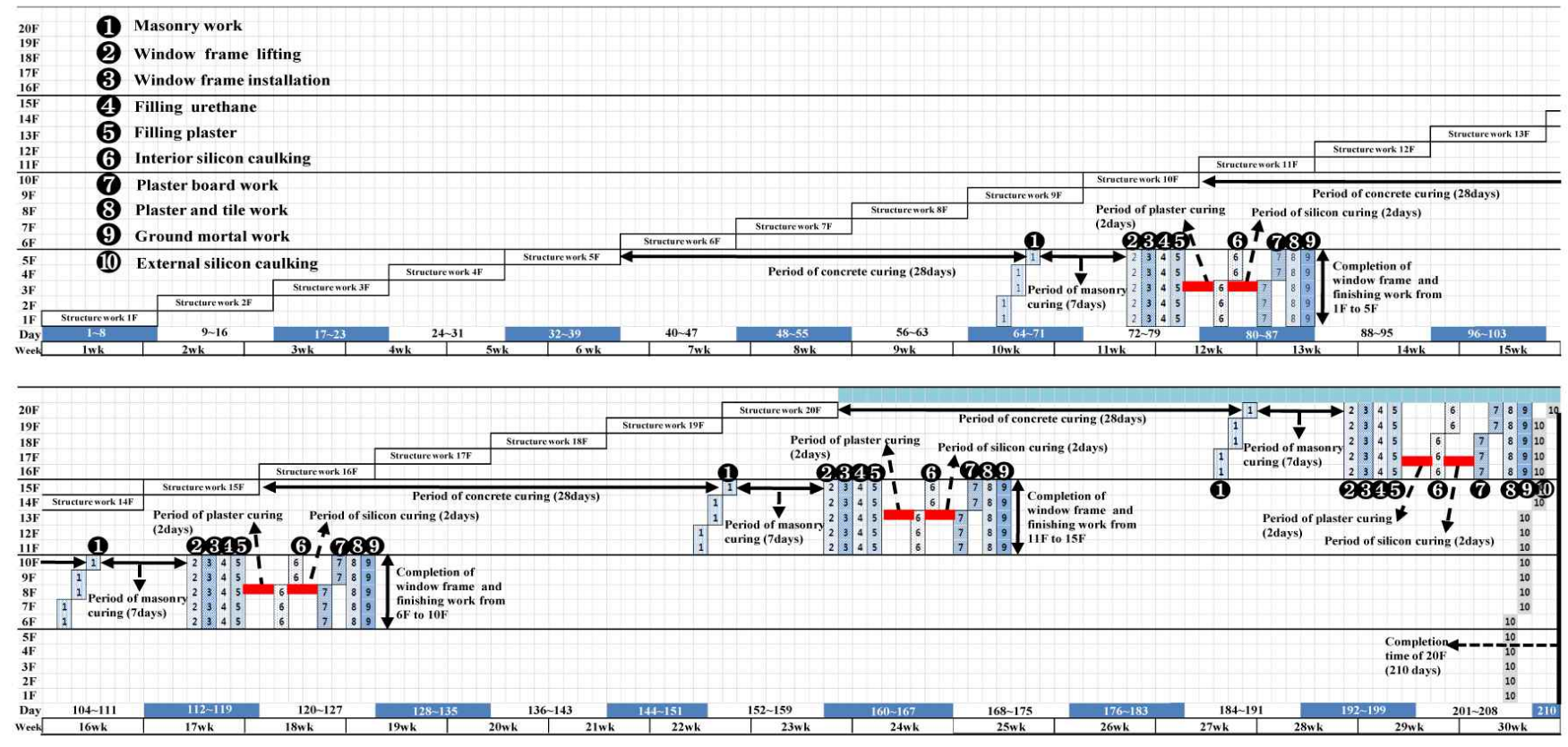

Figure 19. The overall work duration using PVC window frame installation method integrated with Gangform

plaster work, masonry work and the construction of internal and external windows was included in the calculation. External window frame installation work was included in the structure work. Precedent and followup works (structure work, masonry, lamination board, plaster works, etc.) directly related to the structure work and window frame construction were considered for process plan. Due to the unification of the concrete and external window frame, external window frame mortar and urethane filling work time were excluded. By calculating the total period of construction related to structure work and windows of 80 households, it was estimated to take about 210 days (Figure 19).

\subsubsection{Analysis of Construction Period of Improved Model of Gangform Integrated PVC Window Frame Pre-installation Method}

If the improved model of Gangform integrated PVC window frame pre-installation method is applied, a 7day cycle for structure work construction was found to be feasible by minimizing mixing with the structure work process due to the simplification of the installation work of mount, WEP and protectors (Figure 20).

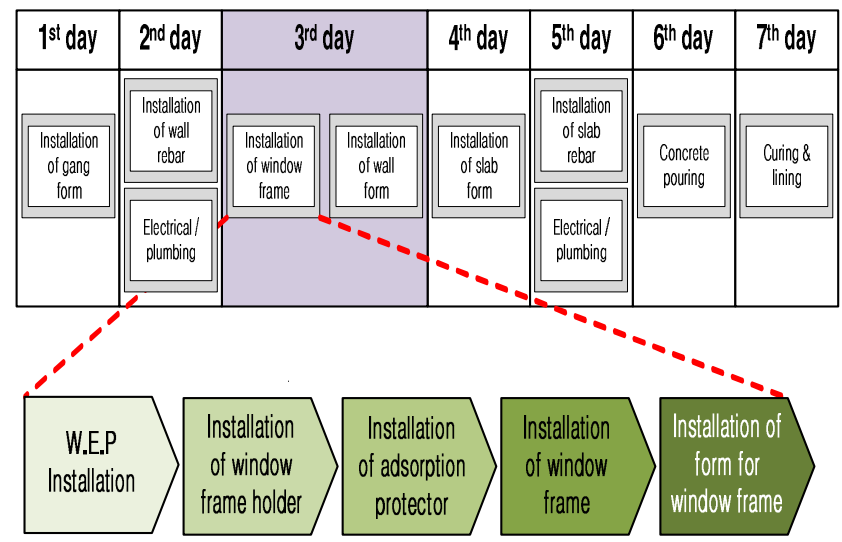

Figure 20. The structure work cycle as using new method

To calculate the construction period of the improved model, construction period of 80 34Pyeong apartment houses was analyzed with the same condition as Gangform integrated PVC window frame pre-installation method and the existing window frame construction method.

Figure 21 predicted the construction period 


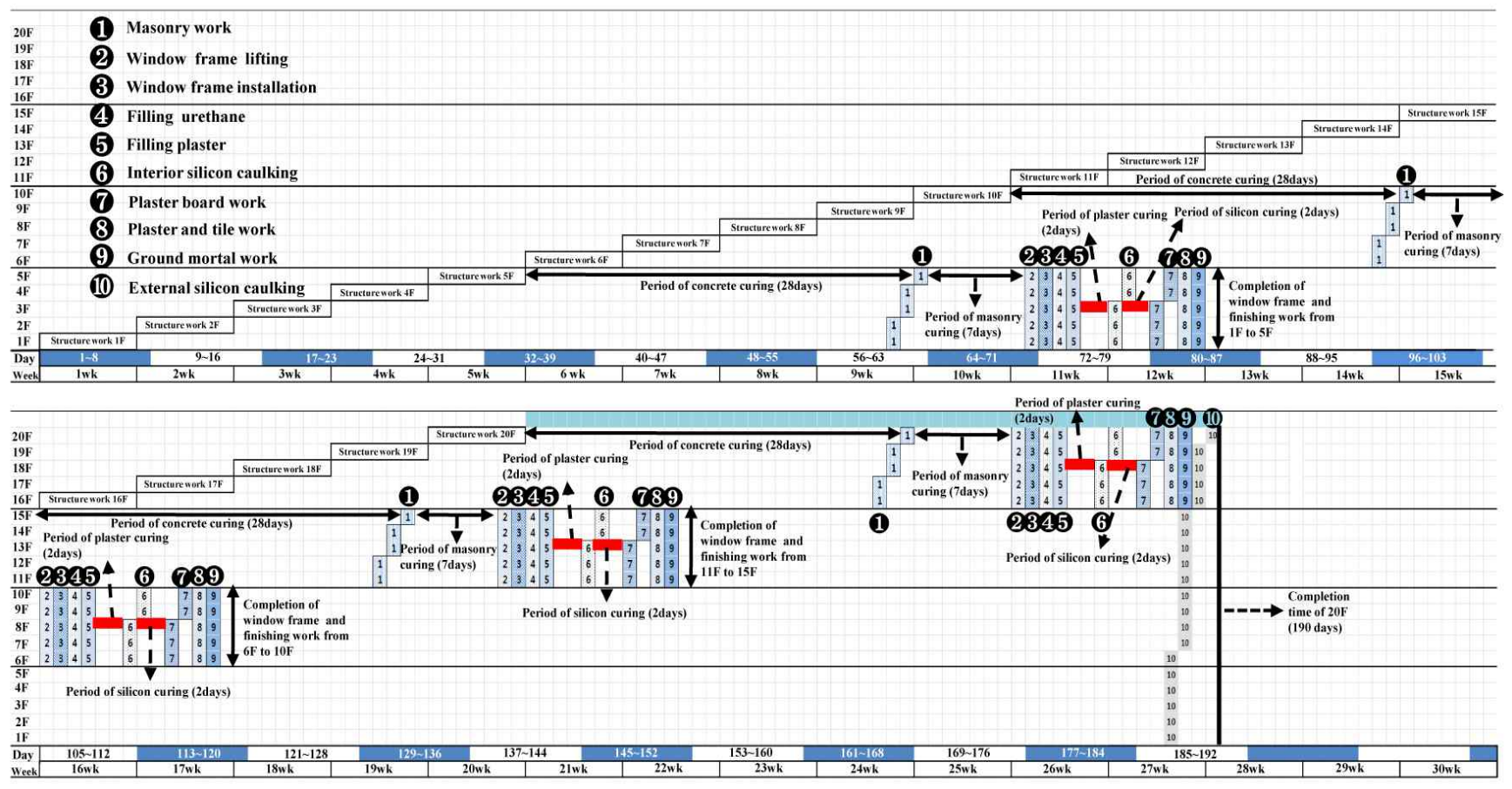

Figure 21. The overall work duration using the new method

related to structure work and window frame through an analysis of the new method process applied with Gangform dedicated for PVC window frame pre-installation. By analyzing the construction period of the improved model of Gangform integrated PVC window frame preinstallation method, the total construction period for structure and window frame works of 80 households in 34-Pyeong units was found to be 190 days. Accordingly, it was analyzed that construction period could be reduced from 6 to 20 days compared not only to the total construction period of 196 days spent when the existing window frame construction method is applied but also to the total construction period of 210 days spent when the Gangform integrated PVC window frame pre-installation method is applied.

\subsection{Analysis of Economic Feasibility of Improved Model of Gangform Integrated PVC Window Frame Pre-Installation Method}

This study examined and analyzed the required number of workers and material costs to analyze the economic feasibility of the improved model of the Gangform integrated PVC window frame preinstallation method. Economic feasibility was analyzed based on 80 units of 34-Pyeong apartment houses. For labor cost and material cost, the average value obtained through interviews conducted in field visits was used, and the workers were calculated based on the results of an analysis of productivity. Saving of quantities due to the dedicated use of rubber protectors was considered when analyzing the economy of the improved model of the Gangform integrated PVC window frame preinstallation method, in addition to the the cost needed to remove the protectors installed on the upper, left and right part of window frame.

Table 5 shows the analysis of the economy of the improved model of the Gangform integrated PVC window frame pre-installation method, and excludes the work sections overlapping with the existing 
method as well as the Gangform integrated PVC window frame installation method. Construction cost was derived by multiplying unit cost by each work quantity and quantity of labor. As a result, it was found to require a construction cost of about 34,418,960 for 80 units of 34 Pyeong apartment houses. It is analyzed to reduce construction costs by about 1,000,000 won $\sim 90,000,000$ won compared to the existing method and the Gangform integrated PVC window installation method if the proposed improved model is applied.

In addition, since the construction period is shortened by 6 to 20 days, the construction cost saving effect is expected to be much higher, in consideration of the labor cost and indirect cost required for the same period.

Table 5. Economic feasibility of the new method

\begin{tabular}{|c|c|c|}
\hline Type of work & Unit cost & Construction cost \\
\hline Window frame salvage & 100,000won·day & 800,000 won \\
\hline Installation of window frame & 110,000 won.day & $7,480,000$ won \\
\hline $\begin{array}{l}\text { Filling interior plaster and } \\
\text { urethane (Sliding Windows ) }\end{array}$ & 700won.m & 380,800won \\
\hline $\begin{array}{l}\text { Filling interior plaster and } \\
\text { urethane(double windows ) }\end{array}$ & 1000 won $\cdot m$ & 496,000won \\
\hline Interior silicon caulking $5 \mathrm{~T}$ & 600 won $\cdot m$ & 624,000 won \\
\hline External silicon caulking $5 \mathrm{~T}$ & 600 won $\cdot \mathrm{m}$ & $2,460,000$ won \\
\hline P.E form & 200won·m & 720,000won \\
\hline Rubber adsorption protector & 30,000won $\cdot m$ & 13,122,000won \\
\hline Plate pin & 1,800won.EA & $10,800,000$ won \\
\hline Bracket & 2,300won.EA & $1,729,600$ won \\
\hline Angle & 2,000won:EA & 880,000 won \\
\hline Anchor & 120won·EA & 10,6560won \\
\hline Window work cost & 110,000 won $\cdot$ day & 880,000 won \\
\hline Window frame work cost & $16,000,000$ won & $1,600,000$ won \\
\hline $\begin{array}{l}\text { Not installed safety rail (labor } \\
\text { cost) }\end{array}$ & 70,000won ·day & $1,400,000$ won \\
\hline $\begin{array}{l}\text { Not installed safety rail (material } \\
\text { cost) }\end{array}$ & $10,000 \cdot E A$ & $1,000,000$ won \\
\hline \multicolumn{2}{|l|}{ Overall cost } & $34,418,960$ won \\
\hline
\end{tabular}

Table 6 compares and analyzes methods in terms of the economy and shows that the economy of the improved model of Gangform integrated PVC window frame pre-installation method is the highest.

Table 6. Comparative analysis of economic feasibility

\begin{tabular}{|c|c|c|c|}
\hline Type of work & $\begin{array}{l}\text { Conventional } \\
\text { method }\end{array}$ & $\begin{array}{l}\text { PVC window } \\
\text { frame } \\
\text { pre-installation } \\
\text { method integrated } \\
\text { with Gangform }\end{array}$ & $\begin{array}{l}\text { Improved } \\
\text { model }\end{array}$ \\
\hline Window frame lifting & $1,600,000$ won & 800,000 won & 800,000 won \\
\hline $\begin{array}{l}\text { Installation of window } \\
\text { frame }\end{array}$ & $3,080,000$ won & $7,480,000$ won & $7,480,000$ won \\
\hline $\begin{array}{c}\text { Filling interior plaster } \\
\text { and urethane (Sliding } \\
\text { Windows ) }\end{array}$ & 817,600 won & 380,800won & 380,800 won \\
\hline $\begin{array}{c}\text { Filling interior plaster } \\
\text { and urethane(double } \\
\text { windows ) }\end{array}$ & $3,472,000$ won & 496,000won & 496,000won \\
\hline Interior silicon caulking & $1,560,000$ won & 624,000 won & 624,000 won \\
\hline Extemal silicon caulking & $9,000,000$ won & $2,460,000$ won & $2,460,000$ won \\
\hline P.E form & & 720,000won & 720,000won \\
\hline $\begin{array}{l}\text { Rubber adsorption } \\
\text { protector }\end{array}$ & & $108,000,000$ won & 13,122,000won \\
\hline Plate pin & & $10,800,000$ won & 10,800,000won \\
\hline Bracket & $11,628,800$ won & $1,729,600$ won & $1,729,600$ won \\
\hline Angle & 3,776,000won & 880,000 won & 880,000 won \\
\hline Anchor & 222,720won & 10,6560 won & 10,6560 won \\
\hline $\begin{array}{c}\text { Window frame work } \\
\text { cost }\end{array}$ & & 880,000 won & 880,000 won \\
\hline Window work cost & & $1,600,000$ won & $\begin{array}{c}1,600,000 \text { wo } \\
n\end{array}$ \\
\hline $\begin{array}{l}\text { Not installed safety rail } \\
\text { (labor cost) }\end{array}$ & & $1,400,000$ won & $\begin{array}{c}1,400,000 \text { wo } \\
n\end{array}$ \\
\hline $\begin{array}{l}\text { Not installed safety rail } \\
\text { (material cost) }\end{array}$ & & $1,000,000$ won & $\begin{array}{c}1,000,000 \text { wo } \\
n\end{array}$ \\
\hline Amount & $35,157,120$ & $129,296,960$ won & $34,418,960$ won \\
\hline
\end{tabular}

\subsection{Analysis of Field Applicability of Improved Model of Gangform Integrated PVC Window Frame Pre-installation Method}

This study conducted a survey on 28 site managers to examine the field applicability of the 
improved model of the Gangform integrated PVC window frame pre-installation method. The survey was organized to analyze the economic feasibility and quality of the improved model of the Gangform integrated PVC window frame pre-installation method, as well as potential solutions to problems generated in the field application of the Gangform integrated PVC window frame pre-installation method. Regarding the possibility of shortening the construction period compared to the existing construction method, the easy adjustment of verticality/horizontality, and the possibility of securing more economic construction, $71 \%$, $61 \%$ and $79 \%$ of survey respondents rated the proposed method 'high' (Figure 22).

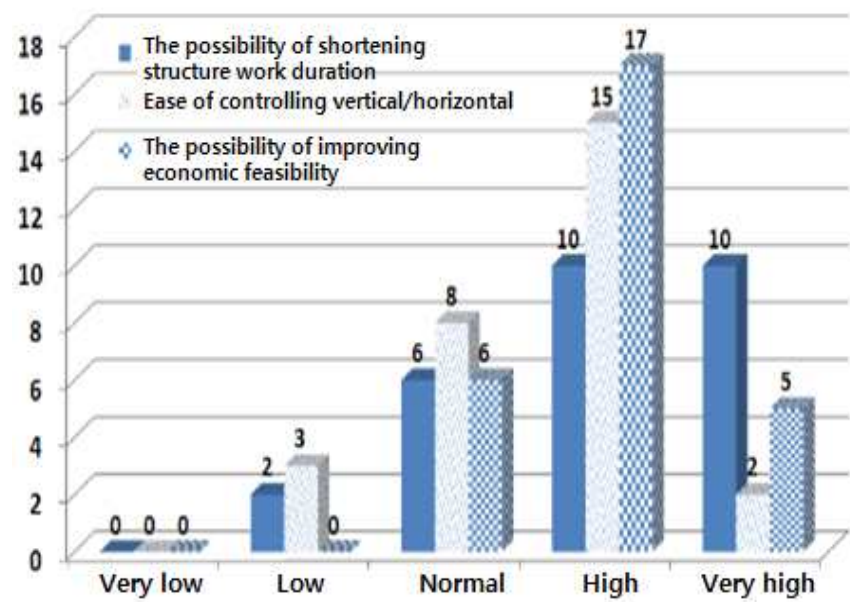

Figure 22. Possibility of solving problems of the PVC window frame installation method integrated with Gangform

In addition, in the examination and analysis of the field applicability of the improved model of Gangform integrated PVC window frame preinstallation method from the aspect of quality/economy compared to the existing method, $82 \%$ of respondents answered 'normal' for the quality aspect, and $89 \%$ of respondents answered 'normal' for the economy aspect. Accordingly, the improved model of the Gangform integrated
PVC window frame pre-installation method proposed in this study was found to be excellent in terms of the possibility of problem-solving as well as quality/economy compared to the existing method (Figure 23).

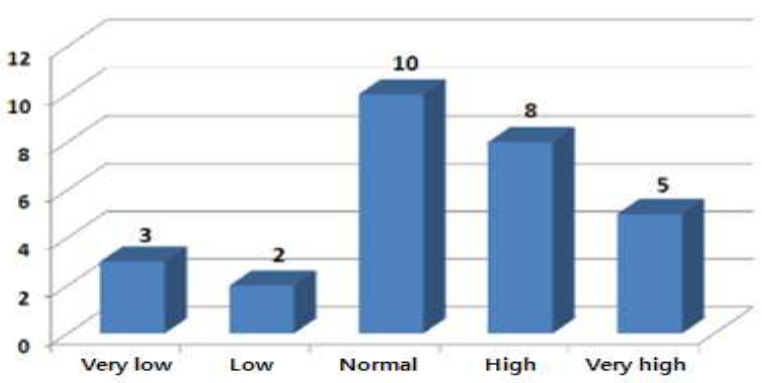

(a) The assessment of field applicability in terms of quality

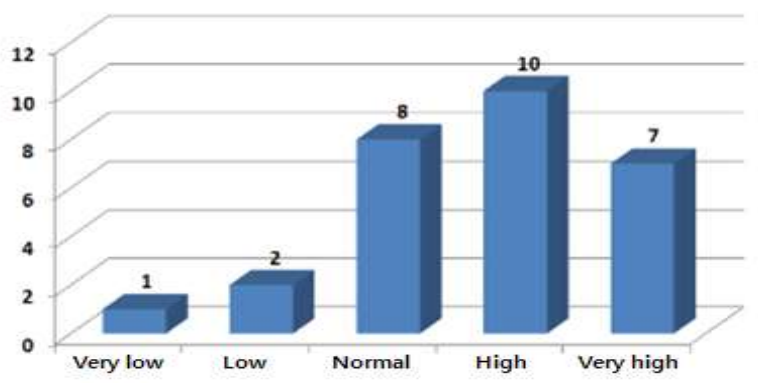

(b) The assessment of field applicability in terms of economy

Figure 23. The result of the field applicability analysis

\section{Conclusion}

The conclusions drawn by this study can be summarized as follows.

1) Problems of the existing window construction method and the PVC window frame preinstallation method were derived through a literature analysis and field visits. As a result, several problems were identified, including poor fixing of the window frame due to damage and deformation of bracket, leakage around the window frame, extension of construction period of structure work construction due to interference between works, difficulties in vertical/horizontal 
adjustment of window frame, and low economy due to the use of high cost protectors to protect the window frame.

2) An improved model of the Gangform integrated PVC window frame pre-installation method was proposed to solve the problems of existing window frame installation methods. The improved model was designed to simplify installation and construction in the field through the integration of the Gangform and mount using the hinge, as well as protectors and WEP. In addition, the position of the window frame could be identified through graduation outside the Gangform, and adjusted using a fine vertical/horizontal control device if the installation position of structure work exceeds the tolerance.

3) By analyzing the construction period required in the existing method and the improved model of the Gangform integrated PVC window frame preinstallation method, it was found that the proposed method shortened the construction period by 20 days compared to the PVC window frame pre-installation method and by 6 days compared to existing window frame construction methods, based on 80 units of 34 Pyeong houses. In addition, in terms of economic performance, it was analyzed to reduce construction cost by about 90 million won compared to the PVC window frame preinstallation method, and by about 1 million won compared to the existing method. That is, the improved model of the Gangform integrated PVC window frame pre-installation method has excellent performance in terms of construction period and costs compared to the Gangform integrated PVC window frame pre-installation method. While its effects of construction period shortening and cost saving are not significant compared to the existing method, it can solve the problems of the existing method (leakage around window frame, poor verticality/horizontality of window frame, low productivity due to field work). In addition, the use of the proposed improved model is expected to be very high compared to the existing method, as it can shorten the overall construction period through the early execution of subsequent finishing works and improvements in quality if the improved model is applied in the field.

4) Through the survey to analyze the field applicability of the improved model of the Gangform integrated PVC window frame preinstallation method, the proposed method was analyzed to be evaluated very highly in terms of its potential to solve the problems of the existing method related to quality and economy. Accordingly, the field applicability of the improved model of the Gangform integrated PVC window frame preinstallation method propased through this study is considered to be very high.

\section{Acknowledgement}

This research was supported by Inha University.

\section{References}

1. Architectural Institute of Japan. [AIJ Building Materials and Construction Procedure-JASS 16 Windows and Shutters Work]. 3rd ed. Tokyo (JP): c2008. 17 p. Japanese.

2. Kim KD, Cho SJ, Koo KJ. A Study on the Development of the Systems for Apartment Doors and Windows. Journal of the Architectural Institute of Korea. 1995 Mar;11(3):27-35.

3. Rosen HJ, Heineman T. Architectural materials for construction. 1st ed. Newyork: McGrawHill; 2006. 203 p.

4. Korea land \& housing Corporation (Korea). [A study on installation of window frame about consumer's damages]. Seoul (Korea): Korea land \& housing Corporation, Agency for Industrial Products of Housing; 2007. p. 8-9. Korean. 
5. Kajima Corporation. [Construction Handbook vol.16, Windows Work]. 1st ed. Tokyo (JP): c1989. 48 p. Japanese.

6. Lee SD. inventors; PLUS CHANGHO CORP, assignee. [A horizontal and vertical adjustment device for a door frame]. KOREA patent KR 100733563. 2005 June 22. Korean.

7. Uh SJ. inventors; PLUS CHANGHO CORP, assignee. [A execution method and structure of windows]. KOREA patent KR 200269611. 2002 Mar 13. Korean.

8. LG HAUSYS CORP., [The PVC Window Frame Installation integrated with Gangform]. 2010 (on patent progress in Korea). Korean. progress. 